\title{
Kajian Ketersediaan Air Tanah Terkait Pemanfaatan Lahan di Kabupaten Blitar
}

\author{
Trisno Widodo ${ }^{1}$ \\ Diterima : 7 Februari 2013 \\ Disetujui : 1 Maret 2013
}

\begin{abstract}
East Java Provincial Government has categorized Blitar Regency as water scarce area and is prone to drought therefore resulting in increasing use of groundwater. The study analyzed land use change during 2002-2011 period, water demand, infiltration, and groundwater supply. The study conducted land use analysis (through Landsat image interpretation), runoff and infiltration analysis (using hydro meteorological method), water demand analysis (for domestic, urban, farming, fishery and industry sectors), and groundwater reserve analysis (gap between infiltration and total demand). Interpretation of Landsat image from 2002 and 2011 indicated a significant increase in housing area while showing decrease in other uses which may serve as watershed area such as farmlands, forests, plantations and open spaces. Infiltration analysis indicated that in dry seasons (with very low or zero precipitation) infiltration is limited therefore creating a deficit in groundwater supply. One of the driving factors is the conversion of open spaces into built areas in the last 10 years. The study recommended that the government should maintain the amount of open spaces and increase rain water infiltration by means of ponds, biopores, and absorption wells.
\end{abstract}

Keywords: groundwater, land use, infiltration, water supplies, water availability

\section{ABSTRAK}

Pemerintah Provinsi Jawa Timur menggolongkan Kabupaten Blitar sebagai daerah sulit air bersih dan rawan kekeringan sehingga penggunaan air tanah cenderung meningkat. Penelitian ini menganalisis perubahan lahan tahun 2002-2011, kebutuhan air, infiltrasi, dan ketersediaan air tanah. Penelitian ini melakukan analisis pemanfaatan lahan (melalui interpretasi citra Landsat), analisis run off dan infiltrasi (menggunakan metode hidrometeorologi), analisis kebutuhan air (sektor domestik, perkotaan, pertanian, peternakan, perikanan dan industri) serta analisis ketersediaan air tanah (dari selisih infiltrasi dan total kebutuhan air tanah). Interpretasi citra Landsat 2002-2011 mengindikasikan peningkatan signifikan area permukiman serta penurunan pemanfaatan lahan yang berpotensi sebagai daerah resapan seperti persawahan, hutan, perkebunan, dan lahan kosong. Analisis infiltrasi mengindikasikan bahwa pada bulan kering (dengan curah hujan kecil/nol) infiltrasi terbatas sehingga menyebabkan defisit ketersediaan air tanah. Salah satu faktor penyebabnya adalah tingginya perubahan lahan terbuka menjadi lahan terbangun terutama dalam kurun waktu 10 (sepuluh) tahun terakhir. Penelitian ini merekomendasikan agar pemerintah mempertahankan luasan lahan terbuka dan meningkatkan tingkat resapan air hujan melalui pembuatan embung, biopori, atau sumur resapan.

Kata Kunci : air tanah, pemanfaatan lahan, infiltrasi, kebutuhan air, ketersediaan air

\footnotetext{
${ }^{1}$ Dinas Cipta Karya dan Tata Ruang Kabupaten Blitar, Jawa Timur

Kontak Penulis : trisno_widodo@yahoo.com
} 


\section{PENDAHULUAN}

Air telah menjadi kebutuhan yang vital bagi kehidupan manusia. Ketersediaan air di muka bumi ini hanya sekitar 2.5\% dari total volume air yang ada (UNESCO 1978 dalam Kodoatie dan Sjarief, 2010). Air tanah adalah air permukaan yang mengalami infiltrasi di daerah isian sehingga terdapat di bawah permukaan bumi (Juanda dan Hutasoit, 1999). Seiring laju pertumbuhan penduduk yang semakin tinggi, maka kebutuhan air pun semakin meningkat. Pemanfaatan air tanah sebagai sumber air bersih menjadi solusi terbaik dan termurah. Hal ini menyebabkan keberadaan air tanah semakin berkurang. Selain itu, perubahan fungsi lahan juga menyebabkan air yang seharusnya dapat terserap, menjadi run off yang mengalir ke dalam sungai dan terus ke laut. Dampak langsungnya adalah berkurangnya ketersediaan air tanah (kekeringan).

Saat ini, Pemerintah Provinsi Jawa Timur mencatat Kabupaten Blitar dilanda kekeringan dan kekurangan air bersih (Surabaya Post Online, 2011). Bencana kekeringan ini terjadi akibat perubahan lahan (Koran Tempo, 2009). Untuk itu perlu dilakukan kajian ketersediaan air tanah terkait pemanfaatan lahan di Kabupaten Blitar dengan cara:

1. Menganalisis pemanfaatan lahan tahun 2011;

2. Menganalisis besaran kebutuhan air di Kabupaten Blitar sebagai sumber air untuk memenuhi kebutuhan domestik, perkotaan, pertanian, perikanan, peternakan dan industri;

3. Menganalisis nilai infiltrasi air;

4. Menganalisis ketersediaan air tanah;

5. Menganalisis perubahan pemanfaatan lahan tahun 2002 dan 2011;

6. Merumuskan pemanfaatan ruang dalam kaitan menjaga kelangsungan ketersediaan air tanah sebagai sumber air.

\section{METODE PENELITIAN}

Metodologi penelitian yang Penulis lakukan, yaitu :

1. Analisis Perubahan Pemanfaatan Lahan

Analisis perubahan pemanfaatan lahan ini diperoleh dari pengolahan citra satelit landsat tahun 2002 dan 2011 menggunakan software ER Mapper.

2. Analisis Infiltrasi

Infiltrasi dihitung menggunakan metode hidrometeorologi (FJ Mock) dengan data curah hujan, lama penyinaran matahari, temperatur, tekanan uap air, kecepatan angin, evapotranspirasi dan debit sungai minimal (Juanda \& Hutasoit, 1999).

3. Analisis Kebutuhan Air

Perhitungan kebutuhan air berdasarkan kebutuhan sektor domestik dan perkotaan, pertanian, peternakan, perikanan, dan industri (Bappenas, 2006).

4. Analisis Ketersediaan Air Tanah

Ketersediaan air tanah didapat dari selisih infiltrasi dan kebutuhan air total. Kebutuhan air total dipenuhi dari air tanah dan air permukaan.

\section{KAJIAN HIDROLOGI DALAM PEMANFAATAN LAHAN}

\section{Siklus Hidrologi}

Siklus hidrologi ini dimulai dari penguapan air yang berada di permukaan laut maupun daratan. Uap air ini naik mengikuti arah angin (udara) dan terkumpul dalam awan-awan di udara. 
Kemudian mengalami kondensasi dan membentuk butir-butir air yang akan jatuh ke permukaan bumi sebagai presipitasi dalam bentuk air hujan atau salju yang jatuh ke permukaan bumi, sungai, laut, maupun menguap kembali. Jumlah air dalam siklus ini relatif tetap baik itu sebagai air permukaan maupun air tanah.

\section{Cekungan Air Tanah}

Keterdapatan air tanah ini berada pada lapisan dalam suatu cekungan air tanah. Berdasarkan cekungan air tanah (CAT) tersebut, maka wilayah Kabupaten Blitar terbagi menjadi 3 bagian :

1. CAT Brantas yang meliputi Blitar Utara seluas $857,95 \mathrm{Km}^{2}$.

2. Non CAT yang meliputi Blitar Tengah seluas $413,09 \mathrm{Km}^{2}$.

3. CAT Bulukawang yang meliputi Blitar Selatan seluas $317,75 \mathrm{Km}^{2}$.

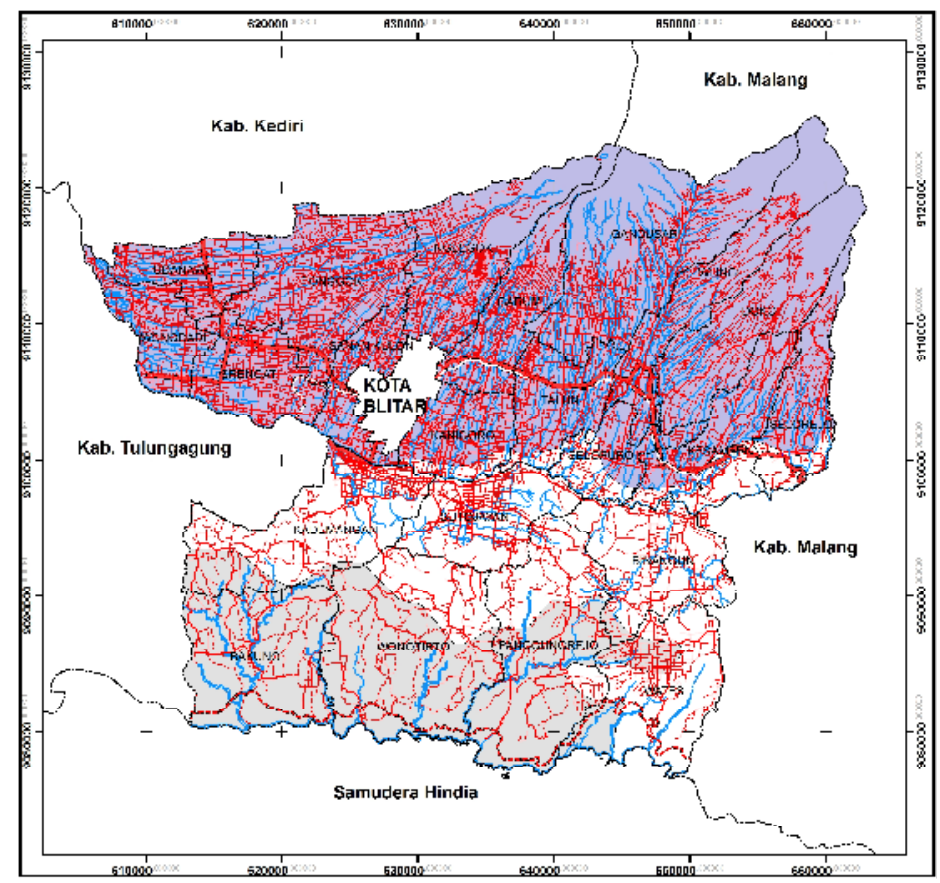

Sumber : Kementerian Energi dan Sumber Daya Mineral, 2011

GAMBAR

PETA CEKUNGAN AIR TANAH KABUPATEN BLITAR

\section{Pemanfaatan Lahan}

TABEL 1

KENAIKAN DEBIT ALIRAN PERMUKAAN AKIBAT PENGGUNAAN LAHAN

\begin{tabular}{llll}
\hline \multirow{2}{*}{ Penggunaan Lahan } & \multicolumn{2}{l}{ Debit Puncak $\left(\mathrm{m}^{3} / \mathrm{dt}\right)$} & \multirow{2}{*}{ Kenaikan } \\
\cline { 2 - 3 } & Min & Maks & \\
\hline Hutan & 10 & 10 & Referensi \\
\hline Rerumputan & 23 & 25 & $2-2.5 \mathrm{kali}$ \\
\hline Taman & 17 & 50 & $2-5 \mathrm{kali}$ \\
\hline Sawah & 25 & 90 & $2.5-9$ kali \\
\hline Pemukiman & 50 & 200 & $5-20$ kali \\
\hline Industri/Niaga & 60 & 250 & $6-25$ kali \\
\hline Beton/Aspal & 63 & 350 & $6.3-35$ kali \\
\hline Sumber : Kodoatie dan Sjarief, 2010 & & &
\end{tabular}


Laju run off air hujan yang turun ke permukaan bumi sebagian besar dipengaruhi oleh pemanfaatan lahan di suatu kawasan. Pemanfaatan lahan dapat diketahui dari tutupan lahan merupakan kondisi yang menggambarkan penutup lahan yang nampak di permukaan bumi. Untuk mengetahui perubahan pemanfaatan lahan dapat mengacu pada citra satelit.

Infiltrasi

Infiltrasi air hujan didapat menggunakan Metode Hidrometeorologi (FJ Mock, 1973):

$\mathrm{dS}=\mathrm{CH}-(\mathrm{BFn}+\mathrm{Ro}+$ Eto $)$

Dimana : dS : Banyaknya curah hujan yang dapat meresap ke lapisan akifer

$\mathrm{CH}$ : Curah Hujan

BF : Aliran dasar sungai / debit minimum (base flow)

Ro : Surface Run Off (limpasan air permukaan)

Eto : Evapotranspirasi

\section{a. Curah Hujan}

Curah hujan rata-rata efektif yang dilakukan dengan metode aritmatik.

$$
\mathrm{CHEr}=\mathbf{1} / \mathrm{n}(\mathrm{R} 1+\mathrm{R} 2+\mathrm{R} 3 \ldots . .+\mathrm{Rn})
$$

b. Base Flow

Merupakan jumlah aliran air dasar pada permukaan

BF = Qmin rata-rata/ kualitas $=$ debit sungai

\section{Luas Daerah Penelitian}

c. Surface Run Off (Ro)

Merupakan aliran limpasan permukaan.

\section{Ro = Qrata-rata - Qminimal}

Luas Daerah Penelitian

\section{d. Evapotranspirasi}

Merupakan proses penguapan dibantu tanaman, perhitungannya menggunakan metode Pen Mann.

$$
\begin{aligned}
\text { Pe1 }= & \operatorname{lgA} \times(1-\mathrm{a}), \mathrm{Pe}=(0.18+0.62 \mathrm{~S}), \mathrm{Pe}=\delta \mathrm{T}^{4} \times\left(0.056-0.08 \mathrm{e}^{1 / 2}\right) \times(0.1+0.9 \mathrm{~S}) \\
\text { Pe4 }= & 1 \times(\pi / \mathrm{Y}), \quad \mathrm{Pe} 5=\underline{0.26}, \mathrm{Pe} 6=\mathrm{e}_{\mathrm{w}}-\mathrm{e}, \mathrm{Pe} 7=(1+0.54 \mathrm{~V}) \\
& 59(1+\pi / \mathrm{Y}) \quad(1+\pi / \mathrm{Y}) \\
\mathrm{Pe}= & \{[(\operatorname{Pe} 1 \times \mathrm{Pe} 2)-\mathrm{Pe} 3] \times \mathrm{Pe} 4\}+\{\operatorname{Pe} 5 \times \mathrm{Pe} 6 \times \mathrm{Pe} 7\}
\end{aligned}
$$

\section{Dimana :}

$\mathrm{Pe} \quad=$ Potensial evapotranspirasi

$\lg \mathrm{A}=$ Maksimum radiasi matahari $(\mathrm{cal} / \mathrm{cm} 2)$

$\mathrm{a} \quad=$ Koefisien Albedo penguapan akibat pantulan permukaan/a

$\mathrm{S}=$ Penyinaran matahari (\%) rata-rata per hari dalam bulan tertentu

$\delta=$ Konstanta Stefan Bolzmann $=1.1825 * 10^{-7} \mathrm{cal} / \mathrm{cm}^{2} /$ hari $/{ }^{\circ} \mathrm{K}$

$\mathrm{T} \quad=$ Temperatur udara (oK) rata-rata dalam satu bulan tertentu

e = Tekanan uap air rata-rata dalam satu bulan tertentu (milibar)

ew = Tekanan uap air jenuh / maksimum rata-rata dalam satu bulan tertentu (milibar)

(Tabel A.3)

$\mathrm{V} \quad=$ Kecepatan angin rata-rata selama satu bulan tertentu (mil/jam)

$\mu \quad=$ Kemiringan kurva hubungan tekanan uap air jenuh terhadap temperatur

(Tabel A.4)

$\mathrm{Y} \quad=$ Konstanta psychometric untuk tekanan $1015 \mathrm{mb}$ 
Asumsi yang digunakan dalam Potensial Evapotranspirasi adalah ketersediaan air yang cukup di alam, tetapi kenyataannya kondisi air di alam tidak sama setiap saat, sehingga perlu memperhitungkan waktu tidak terjadi hujan dengan menghitung evapotranspirasi minimal:

$$
\text { Et }=\mathrm{Pe}-\mathrm{dE}, \quad \mathrm{dE}=\mathrm{Pe} * \mathrm{~m} *(30-\mathrm{n}) / 30
$$

\section{Dimana :}

$\mathrm{dE}=$ Perbedaan antara Pe dan Et $(\mathrm{mm} / \mathrm{b} / \mathrm{n})$

$\mathrm{Pe}=$ Potensial Evapotranspirasi $(\mathrm{mm} / \mathrm{b} / \mathrm{n})$

Et = Evapotranspirasi Terbatas ( $\mathrm{mm} / \mathrm{bln})$

$\mathrm{n}=$ Jumlah hari hujan tiap bulan

$\mathrm{m}$ = Perkiraan permukaan yang tidak tertutup tanaman, yaitu :

- Bulan Kering, didefinisikan memiliki < 5 hari hujan;

- Bulan Peralihan, didefinisikan menjadi 5 - 8 hari, nilai $m$ = musim kering;

- Bulan Basah, didefinisikan memiliki 8 hari hujan, nilai $m=10 \%-20 \%$.

\section{Kebutuhan Air}

Kebutuhan air dihitung berdasarkan kebutuhan air untuk berbagai kegiatan manusia yaitu Kebutuhan Air Domestik (Dmk) dan Perkotaan (Pkt). Kebutuhan air domestik untuk memenuhi kebutuhan air penduduk selama 24 jam dihitung berdasarkan SNI 19-6828.1-2002, yaitu :

- Kebutuhan air domestik pedesaan $=\Sigma$ penduduk $\times 365 \times 60 \mathrm{~L}$

- Kebutuhan air domestik perkotaan $=\Sigma$ penduduk $\times 365 \times 120 \mathrm{~L}$

Kebutuhan air perkotaan digunakan untuk memenuhi kebutuhan air berbagai fasilitas umum yang dihitung berdasarkan jumlah penduduk, yaitu 25-40\% tergantung jenis perkotaan dan fasilitas umum yang tersedia (Bappenas, 2006).

TABEL 2

\section{JENIS PERKOTAAN BERDASARKAN JUMLAH PENDUDUK}

\begin{tabular}{lll}
\hline No & Jumlah Penduduk (Jiwa) & Jenis Perkotaan \\
\hline 1 & $50.000-100.000$ & Kecil \\
\hline 2 & $100.000-500.000$ & Sedang \\
\hline 3 & $500.000-1.000 .000$ & Besar \\
\hline 4 & $>1.000 .000$ & Metropolitan \\
\hline 5 & Memiliki $\geq 2$ metropolitan & Megapolitan \\
\hline Sumber : Peraturan Pemerintah 26/2008 &
\end{tabular}

\section{Kebutuhan Air Industri (Ids)}

Menurut penelitian Jabodetabek Water resource Management Study, kebutuhan air industri berdasarkan jumlah karyawan yang bekerja sebesar 500 liter/karyawan/hari (Bappenas, 2006).

\section{Kebutuhan Air Sektor Pertanian (Ptn)}

Kebutuhan air untuk pertanian digunakan untuk irigasi (SNI 19-6828.1-2002):

$A=L \times 3600 \mathrm{det} / \mathrm{jam} \times 24$ jam/hari $\times 120$ hari/musim $\times$ a

Dimana : $A=$ Penggunaan air irigasi

$L=$ Luas sawah (ha)

$\mathrm{a}=$ Standar penggunaan air $(1 \mathrm{l} / \mathrm{det} / \mathrm{ha})$ 


\section{Kebutuhan Air Peternakan (Ptk)}

TABEL 3

KEBUTUHAN AIR UNTUK TERNAK

\begin{tabular}{lll}
\hline No & Jenis Ternak & Kebutuhan Air (L/ekor/hari) \\
\hline 1 & Sapi/kerbau & 40 \\
\hline 2 & Domba/kambing & 5 \\
\hline 3 & Babi & 6 \\
\hline 4 & Unggas & 0,6 \\
\hline Sumber: SNI 19-6828.1-2002
\end{tabular}

Kebutuhan air peternakan dapat dihitung dari perkalian jumlah ternak yang ada di kabupaten tersebut dengan kebutuhan air untuk tiap jenis ternak.

\section{Kebutuhan Air Perikanan (Pik)}

Untuk sektor perikanan, kebutuhan airnya untuk mengisi kolam pada saat awal tanam dan kebutuhan untuk penggantian air, yaitu standarnya sebesar $7 \mathrm{~mm} /$ hari $^{2} \mathrm{~m}^{2}$ (Bappenas, 2006).

\section{Kebutuhan Air Total (D)}

Kebutuhan air total dihitung dengan menjumlahkan kebutuhan air domestik, perkotaan, pertanian, peternakan, perikanan dan industri, yaitu :

$D=$ Dmk + Pkt + Ptn + Ptk + Pik + Ids

\section{Ketersediaan Air Tanah}

Ketersediaan air tanah didapat dari selisih infiltrasi dan kebutuhan air total. Kebutuhan air total ini ada yang dipenuhi dari air tanah dan air permukaan

$\mathbf{P}=\mathrm{dS}-(\mathrm{D}$ - Dap)

Dimana $: P \quad=$ Potensi ketersediaan air tanah

dS $\quad=$ Infiltrasi

Dap = Kebutuhan air yang dipenuhi dari air permukaan

\section{GAMBARAN UMUM}

Wilayah studi meliputi Kabupaten Blitar yang terdiri dari 22 kecamatan dengan letak $111^{\circ} 40^{\prime}-$ $112^{\circ} 10^{\prime}$ bujur timur dan $7^{\circ} 58^{\prime}-8^{\circ} 9^{\prime} 51$ lintang selatan dengan batas-batas wilayah:

- Sebelah Utara : Kabupaten Kediri dan Kabupaten Malang

- Sebelah Timur : Kabupaten Malang

- Sebelah Selatan : Samudera Indonesia

- Sebelah Barat : Kabupaten Tulungagung dan Kabupaten Kediri

- Tengah : Kota Blitar

\section{ANALISIS KETERSEDIAAN AIR TANAH TERKAIT PEMANFAATAN LAHAN}

\section{Analisis Pemanfaatan Lahan Tahun 2011 Berdasarkan Citra Landsat}

Pemanfaatan lahan Kabupaten Blitar tahun 2011 didapat dari citra landsat TM 7 Tahun 2011. 


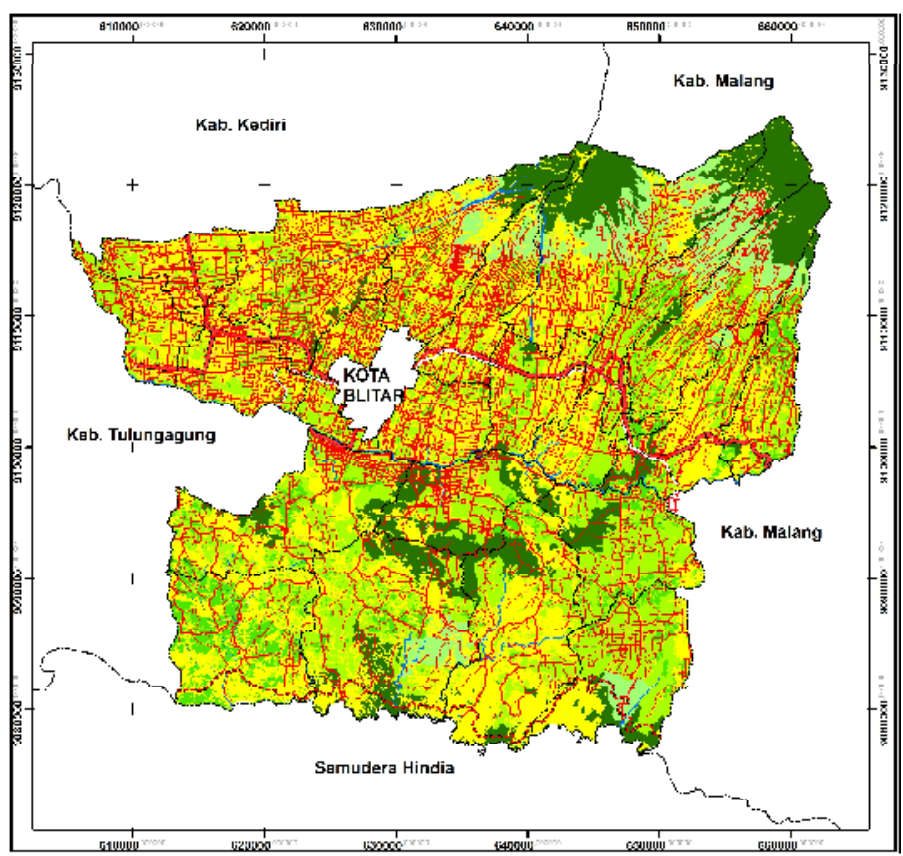

Sumber : Hasil Analisis Penulis, 2012

GAMBAR 2

PETA PEMANFAATAN LAHAN KABUPATEN BLITAR TAHUN 2011

Berdasarkan Gambar 3 terlihat bahwa pemanfaatan lahan terluas sampai terkecil pada tahun 2011, yaitu lahan permukiman dengan luas $46,98 \%$, sawah $25,74 \%$, hutan $11,74 \%$, kebun $9,28 \%$, perkebunan $5,13 \%$, badan air $1,003 \%$ dan lahan kosong 0,13\%. Komposisi pemanfaatan lahan yang mayoritas merupakan lahan permukiman, sangat mempengaruhi kemampuan lahan untuk meresapkan air.

\section{Analisis Infiltrasi}

TABEL 4

PERHITUNGAN INFILTRASI METODE HIDROMETEOROLOGI KABUPATEN BLITAR TAHUN 2010

\begin{tabular}{|c|c|c|c|c|c|c|c|c|c|c|}
\hline No & Kecamatan & $\begin{array}{c}\mathrm{CH} \\
(\mathrm{mm})\end{array}$ & $\begin{array}{c}\text { Eto } \\
(\mathrm{mm})\end{array}$ & $\begin{array}{c}\text { BF } \\
(\mathrm{mm})\end{array}$ & $\begin{array}{c}\text { Ro } \\
(\mathrm{mm})\end{array}$ & $\begin{array}{c}\mathrm{dS} \\
(\mathrm{mm})\end{array}$ & $\begin{array}{c}\mathrm{dS} \\
(\% \mathrm{CH})\end{array}$ & $\begin{array}{c}\text { Volume Infiltrasi } \\
(\mathrm{m} 3)\end{array}$ & $\begin{array}{c}\text { Volume Infiltrasi } \\
(\mathrm{l} / \text { thn })\end{array}$ & $\begin{array}{l}\text { Volume } \\
\text { Infiltrasi }\end{array}$ \\
\hline 1 & 2 & 3 & 4 & 5 & 6 & 7 & 8 & 9 & 10 & 11 \\
\hline 1 & Gandusari & 5359 & 1474.980 & 0.0061 & 0.0110 & 3884.00 & $72.48 \%$ & $342,685,590.46$ & $342,685,590,464$ & 11,017 \\
\hline 2 & Garum & 4532 & 1446.823 & 0.0100 & 0.0177 & 3085.15 & $68.07 \%$ & $168,325,768.98$ & $168,325,768,983$ & 5,412 \\
\hline 3 & Nglegok & 4384 & 1479.017 & 0.0146 & 0.0322 & 2951.65 & $67.33 \%$ & $273,205,050.93$ & $273,205,050,926$ & 8,784 \\
\hline 4 & Selopuro & 3439 & 1468.974 & 2.9531 & 1.3776 & 2305.60 & $67.04 \%$ & $90,587,130.48$ & $90,587,130,483$ & 2,912 \\
\hline 5 & Selorejo & 3675 & 1440.677 & 2.1797 & 1.0363 & 2300.38 & $62.60 \%$ & $120,148,843.12$ & $120,148,843,117$ & 3,863 \\
\hline 6 & Talun & 3503 & 1383.060 & 0.0108 & 0.0194 & 2271.45 & $64.84 \%$ & $113,072,663.71$ & $113,072,663,708$ & 3,635 \\
\hline 7 & Kesamben & 3273 & 1467.584 & 2.0370 & 0.9503 & 2137.11 & $65.30 \%$ & $121,729,665.84$ & $121,729,665,837$ & 3,914 \\
\hline 8 & Udanawu & 3114 & 1306.232 & 0.0323 & 0.0728 & 1983.02 & $63.68 \%$ & $81,263,966.03$ & $81,263,966,027$ & 2,613 \\
\hline 9 & Srengat & 3145 & 1338.758 & 0.0245 & 0.0553 & 1912.87 & $60.82 \%$ & $103,218,335.76$ & $103,218,335,763$ & 3,318 \\
\hline 10 & Bakung & 3016 & 1434.334 & 0.0048 & 0.0087 & 1907.77 & $63.26 \%$ & $212,220,747.07$ & $212,220,747,074$ & 6,823 \\
\hline 11 & Kanigoro & 2933 & 1303.541 & 0.0098 & 0.0174 & 1869.20 & $63.73 \%$ & $103,834,160.30$ & $103,834,160,299$ & 3,338 \\
\hline 12 & Binangun & 3038 & 1406.470 & 0.0015 & 0.7049 & 1757.11 & $57.84 \%$ & $134,928,319.85$ & $134,928,319,846$ & 4,338 \\
\hline 13 & Sanan Kulon & 3101 & 1418.593 & 0.0405 & 0.0895 & 1705.41 & $55.00 \%$ & $56,841,450.30$ & $56,841,450,298$ & 1,827 \\
\hline 14 & Doko & 2698 & 1467.584 & 1.6046 & 0.7629 & 1536.59 & $56.95 \%$ & $109,020,892.73$ & $109,020,892,726$ & 3,505 \\
\hline 15 & Wates & 2403 & 1349.293 & 1.6557 & 0.7872 & 1367.31 & $56.91 \%$ & $94,016,390.01$ & $94,016,390,006$ & 3,023 \\
\hline 16 & Sutojayan & 2282 & 1330.660 & 0.0033 & 0.0059 & 1281.77 & $56.17 \%$ & $210,902,234.96$ & $210,902,234,957$ & 6,781 \\
\hline 17 & Ponggok & 1853 & 1153.962 & 0.0130 & 0.0287 & 1241.54 & $67.00 \%$ & $128,909,598.80$ & $128,909,598,798$ & 4,144 \\
\hline 18 & Panggungrejo & 1763 & 1220.972 & 0.9747 & 0.4547 & 1039.38 & $58.96 \%$ & $123,728,070.35$ & $123,728,070,351$ & 3,978 \\
\hline 19 & Wlingi & 2063 & 1407.031 & 1.7156 & 0.8157 & 982.79 & $47.65 \%$ & $65,217,923.36$ & $65,217,923,360$ & 2,097 \\
\hline 20 & Wonotirto & 1813 & 1356.169 & 0.0121 & 0.0219 & 915.30 & $50.49 \%$ & $40,456,442.81$ & $40,456,442,814$ & 1,301 \\
\hline 21 & Kademangan & 1351 & 1184.285 & 0.0052 & 0.0092 & 864.13 & $63.96 \%$ & $90,975,470.27$ & $90,975,470,268$ & 2,925 \\
\hline 22 & Wonodadi & 829 & 1059.159 & 0.0328 & 0.0739 & 341.05 & $41.14 \%$ & $13,761,544.36$ & $13,761,544,362$ & 442 \\
\hline
\end{tabular}

Sumber : Hasil Analisis Penulis, 2012 
Nilai infiltrasi dihitung dengan menggunakan rumus metode hidrometeorologi (FJ Mock). Berdasarkan Tabel 4, maka di wilayah Kabupaten Blitar volume infiltrasi surplus di semua kecamatan dengan terbesar berada di Kecamatan Gandusari. Faktor yang menyebabkan terjadinya perbedaaan infiltrasi ini adalah faktor sebaran curah hujan yang tidak merata di masing-masing wilayah yang dapat mempengaruhi ketersediaan air di wilayah tersebut serta faktor penguapan/ evapotranspirasi (Purbawa dan Wiryajaya, 2009).

\section{Analisis Kebutuhan Air Total}

TABEL 5

KEBUTUHAN AIR TOTAL KABUPATEN BLITAR TAHUN 2010

\begin{tabular}{|c|c|c|c|c|c|c|c|c|c|}
\hline \multirow{2}{*}{ No } & \multirow{2}{*}{ Kecamatan } & \multicolumn{7}{|c|}{ Kebutuhan Air Sektor (I/detik) } & \multirow{2}{*}{$\begin{array}{l}\text { Kebutuhan Air } \\
\text { Tanah (I/detik) }\end{array}$} \\
\hline & & Domestik & Perkotaan & Pertanian & Peternakan & Perikanan & Industri & Total & \\
\hline 1 & 2 & 3 & 4 & 5 & 6 & 7 & 8 & 9 & 10 \\
\hline 1 & Gandusari & 53.60 & 13.40 & 2,582 & 12.90 & 51.26 & 10.71 & $2,723.86$ & 141.86 \\
\hline 2 & Talun & 57.18 & 14.29 & 2,350 & 18.25 & 27.61 & 12.34 & $2,479.67$ & 129.67 \\
\hline 3 & Garum & 60.94 & 15.23 & 2,193 & 12.22 & 14.12 & 10.00 & $2,305.51$ & 112.51 \\
\hline 4 & Udanawu & 28.49 & 7.12 & 2,222 & 13.27 & 15.24 & 4.61 & $2,290.72$ & 68.72 \\
\hline 5 & Wonodadi & 34.87 & 8.72 & 2,209 & 7.33 & 9.16 & 4.06 & $2,273.14$ & 64.14 \\
\hline 6 & Ponggok & 68.14 & 17.04 & 2,033 & 23.54 & 12.21 & 21.14 & $2,175.06$ & 142.06 \\
\hline 7 & Selopuro & 27.68 & 6.92 & 1,801 & 8.83 & 4.30 & 14.34 & $1,863.08$ & 62.08 \\
\hline 8 & Doko & 26.51 & 6.63 & 1,815 & 7.21 & 0.72 & 2.55 & $1,858.62$ & 43.62 \\
\hline 9 & Kanigoro & 65.84 & 16.46 & 1,725 & 17.15 & 8.86 & 18.08 & $1,851.39$ & 126.39 \\
\hline 10 & Kesamben & 34.09 & 8.52 & 1,758 & 4.77 & 8.80 & 8.85 & $1,823.03$ & 65.03 \\
\hline 11 & Srengat & 55.05 & 13.76 & 1,648 & 22.91 & 9.91 & 12.03 & $1,761.67$ & 113.67 \\
\hline 12 & Nglegok & 56.23 & 14.06 & 1,513 & 11.07 & 63.63 & 43.54 & $1,701.52$ & 188.52 \\
\hline 13 & Wlingi & 62.16 & 15.54 & 1,535 & 6.01 & 17.06 & 6.68 & $1,642.45$ & 107.45 \\
\hline 14 & Sutojayan & 59.74 & 14.94 & 1,266 & 5.44 & 5.76 & 8.23 & $1,360.11$ & 94.11 \\
\hline 15 & Sanan Kulon & 37.34 & 9.34 & 1,207 & 11.76 & 17.57 & 16.01 & $1,299.02$ & 92.02 \\
\hline 16 & Selorejo & 30.42 & 7.60 & 979 & 4.33 & 1.91 & 5.32 & $1,028.58$ & 49.58 \\
\hline 17 & Kademangan & 49.94 & 12.49 & 816 & 22.93 & 4.91 & 23.39 & 929.66 & 113.66 \\
\hline 18 & Wates & 22.26 & 5.57 & 887 & 4.91 & 0.30 & 2.70 & 922.73 & 35.73 \\
\hline 19 & Panggungrejo & 28.63 & 7.16 & 647 & 4.91 & 0.75 & 2.80 & 691.25 & 44.25 \\
\hline 20 & Wonotirto & 24.82 & 6.21 & 288 & 4.90 & 0.34 & 3.05 & 327.32 & 39.32 \\
\hline 21 & Binangun & 30.08 & 7.52 & 122 & 5.12 & 0.41 & 4.01 & 169.13 & 47.13 \\
\hline 22 & Bakung & 17.61 & 4.40 & 128 & 5.40 & 0.27 & 1.47 & 157.15 & 29.15 \\
\hline & Total & 931.62 & 232.90 & 10,575 & 235.17 & 275.07 & 235.90 & $12,485.33$ & $1,910.66$ \\
\hline
\end{tabular}

Sumber: Hasil Analisis Penulis, 2012

Kebutuhan air total dihitung berdasarkan jumlah kebutuhan air sektor domestik, perkotaan, pertanian, peternakan, perikanan, dan industri. Berdasarkan Tabel 5, kebutuhan air total di Kabupaten Blitar Tahun 2010 sebesar 1.910,66 l/detik dengan kebutuhan air terbanyak di Kecamatan Gandusari sebesar 8,03\% dan terkecil di Kecamatan Bakung sebesar 0,58\%. Sektor pertanian dengan kebutuhan air mencapai $84,7 \%$ menjadi sektor dengan kebutuhan air terbesar, sedangkan sektor perkotaan menjadi sektor terkecil sebesar $1,87 \%$. 


\section{Kajian Ketersediaan Air Tanah}

Ketersediaan air tanah merupakan jumlah air yang dapat tersimpan ke dalam tanah dan keluar dalam kurun waktu tertentu (Purbawa dan Wiryajaya, 2009). Ketersediaan air tanah ini, dari selisih infiltrasi dan kebutuhan air tanah. Berdasarkan Tabel 6 terlihat bahwa surplus ketersediaan air tanah terbesar di wilayah Kecamatan Gandusari yaitu 16,08\% dan surplus terkecil di Kecamatan Kademangan sebesar 0,29\%.

TABEL 6

KETERSEDIAAN AIR TANAH DI KABUPATEN BLITAR TAHUN 2010

\begin{tabular}{|c|c|c|c|c|}
\hline No & Kecamatan & $\begin{array}{c}\text { Volume Infiltrasi } \\
\text { (1/detik) }\end{array}$ & $\begin{array}{c}\text { Kebutuhan Air } \\
\text { (1/detik) }\end{array}$ & $\begin{array}{c}\text { Ketersediaan Air } \\
\text { Tanah (1/detik) }\end{array}$ \\
\hline 1 & 2 & 3 & 4 & 5 \\
\hline 1 & Gandusari & $11,017.41$ & 141.86 & $10,875.56$ \\
\hline 2 & Nglegok & $8,783.60$ & 188.52 & $8,595.07$ \\
\hline 3 & Bakung & $6,822.94$ & 29.15 & $6,793.79$ \\
\hline 4 & Sutojayan & $6,780.55$ & 94.11 & $6,686.44$ \\
\hline 5 & Garum & $5,411.71$ & 112.51 & $5,299.20$ \\
\hline 6 & Binangun & $4,337.97$ & 47.13 & $4,290.84$ \\
\hline 7 & Ponggok & $4,144.47$ & 142.06 & $4,002.41$ \\
\hline 8 & Panggungrejo & $3,977.88$ & 44.25 & $3,933.63$ \\
\hline 9 & Kesamben & $3,913.63$ & 65.03 & $3,848.60$ \\
\hline 10 & Selorejo & $3,862.81$ & 49.58 & $3,813.23$ \\
\hline 11 & Talun & $3,635.31$ & 129.67 & $3,505.64$ \\
\hline 12 & Doko & $3,505.04$ & 43.62 & $3,461.43$ \\
\hline 13 & Kanigoro & $3,338.29$ & 126.39 & $3,211.90$ \\
\hline 14 & Srengat & $3,318.49$ & 113.67 & $3,204.82$ \\
\hline 15 & Wates & $3,022.65$ & 35.73 & $2,986.92$ \\
\hline 16 & Selopuro & $2,912.39$ & 62.08 & $2,850.32$ \\
\hline 17 & Kademangan & $2,924.88$ & 113.66 & $2,811.22$ \\
\hline 18 & Udanawu & $2,612.65$ & 68.72 & $2,543.93$ \\
\hline 19 & Wlingi & $2,096.77$ & 107.45 & $1,989.32$ \\
\hline 20 & Sanan Kulon & $1,827.46$ & 92.02 & $1,735.44$ \\
\hline 21 & Wonotirto & $1,300.68$ & 39.32 & $1,261.37$ \\
\hline 22 & Wonodadi & 442.44 & 64.14 & 378.30 \\
\hline & Total & $89,990.04$ & $1,910.66$ & $88,079.38$ \\
\hline
\end{tabular}

Sumber : Hasil Analisis Penulis, 2012

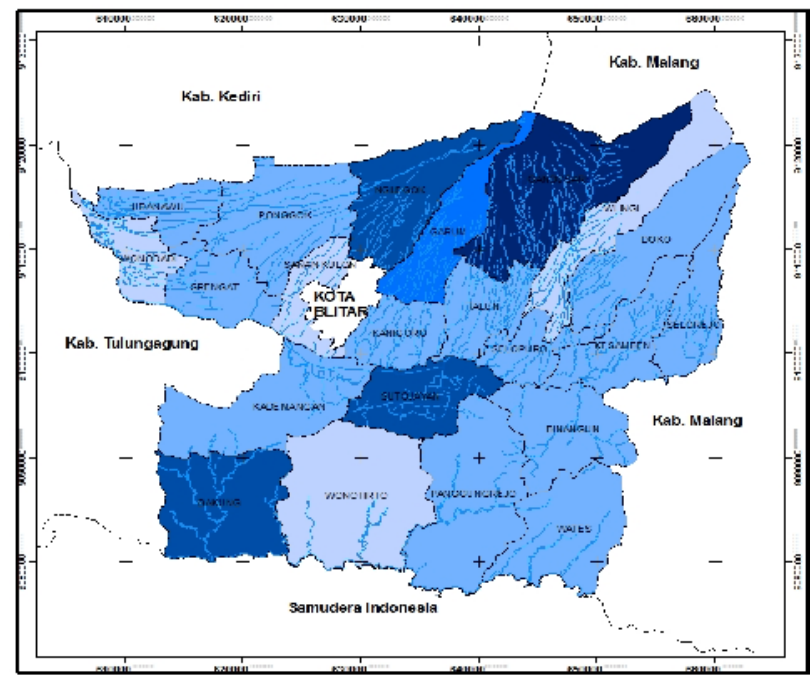

Sumber : Hasil Analisis Penulis, 2012

GAMBAR 3

PETA KETERSEDIAAN AIR TANAH KABUPATEN BLITAR TAHUN 2010 


\section{Analisis Perubahan Pemanfaatan Lahan}

Citra landsat Kabupaten Blitar Tahun 2002 dengan hasil sebagai berikut :

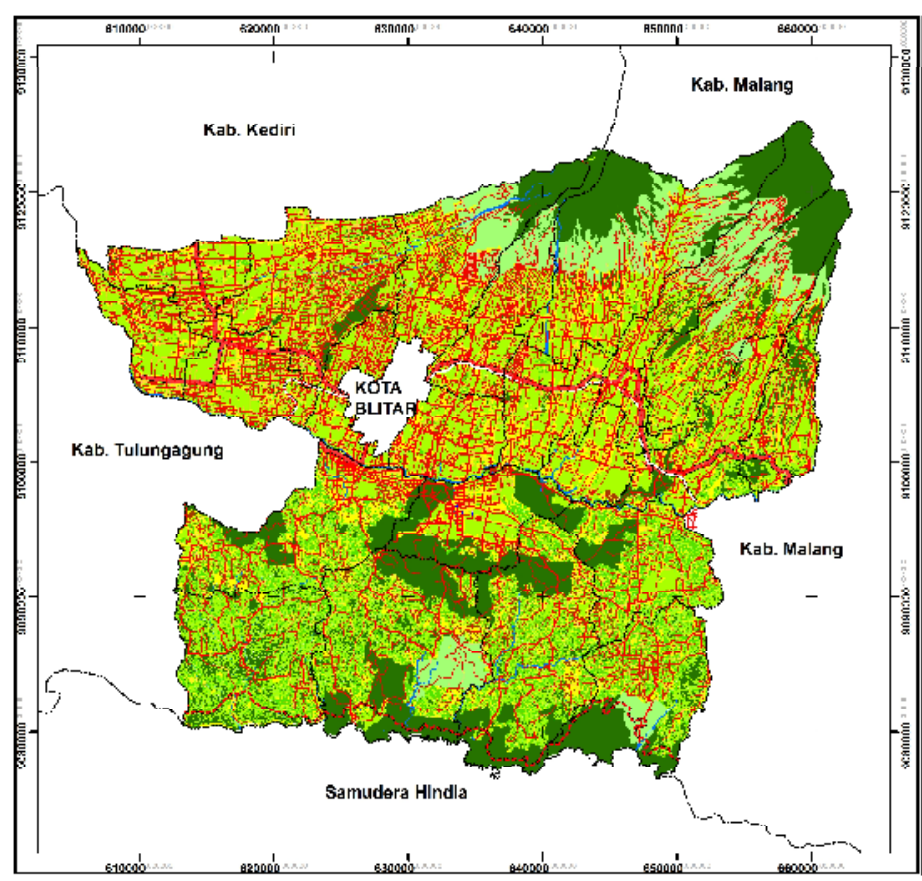

Sumber: Hasil Interpretasi Penulis, 2012

GAMBAR 4

PETA PEMANFAATAN LAHAN KABUPATEN BLITAR TAHUN 2002

Berdasarkan peta pemanfaatan lahan, maka perubahan pemanfaatan lahan, yaitu :

TABEL 7

LUAS PEMANFATAN LAHAN KABUPATEN BLITAR TAHUN 2002 DAN 2011

\begin{tabular}{clccccc}
\hline \multirow{2}{*}{ No } & \multicolumn{3}{c}{ Tahun 2002} & \multicolumn{3}{c}{ Tahun 2011 } \\
\cline { 2 - 7 } & $\begin{array}{c}\text { Pemanfaatan } \\
\text { Lahan }\end{array}$ & $\begin{array}{c}\text { Luas } \\
\left(\mathrm{km}^{2}\right)\end{array}$ & $\begin{array}{c}\text { Luas } \\
(\%)\end{array}$ & $\begin{array}{c}\text { Pemanfaatan } \\
\text { Lahan }\end{array}$ & $\begin{array}{c}\text { Luas } \\
\left(\mathrm{km}^{2}\right)\end{array}$ & Luas (\%) \\
\hline 1 & \multicolumn{1}{c}{2} & 3 & 4 & 5 & 6 & 7 \\
\hline 1 & Sawah & 566,06 & 35.63 & Permukiman & 746,43 & 46.98 \\
\hline 2 & Permukiman & 376,61 & 23.70 & Sawah & 408,89 & 25.74 \\
\hline 3 & Hutan & 330,16 & 20.78 & Hutan & 186,56 & 11.74 \\
\hline 4 & Kebun & 164,88 & 10.38 & Kebun & 147,43 & 9.28 \\
\hline 5 & Perkebunan & 109,30 & 6.88 & Perkebunan & 81,53 & 5.13 \\
\hline 6 & Lahan Kosong & 25,83 & 1.63 & Badan Air & 15,93 & 1.003 \\
\hline 7 & Badan Air & 15,93 & 1.003 & Lahan Kosong & 2,01 & 0.13 \\
\hline
\end{tabular}

Sumber : Hasil Analisis Penulis, 2012

Berdasarkan Tabel 7 dapat diketahui bahwa pemanfaatan lahan terluas tahun 2002 berupa sawah seluas 35,63\% telah berubah pada tahun 2011 menjadi lahan permukiman seluas 46,98\%. Secara keseluruhan laju perubahan pemanfaatan lahan tersebut mencapai $44 \%$. 


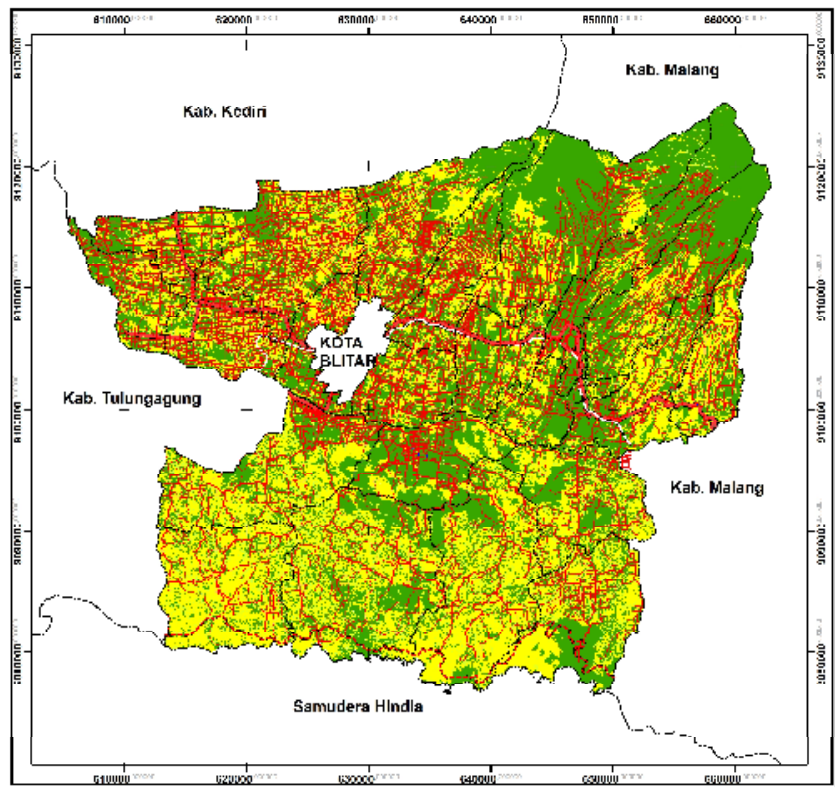

Sumber : Hasil Analisis Penulis, 2012

GAMBAR 5

PETA PERUBAHAN LAHAN KABUPATEN BLITAR TAHUN 2002-2011

\section{Analisis Lahan Terbuka}

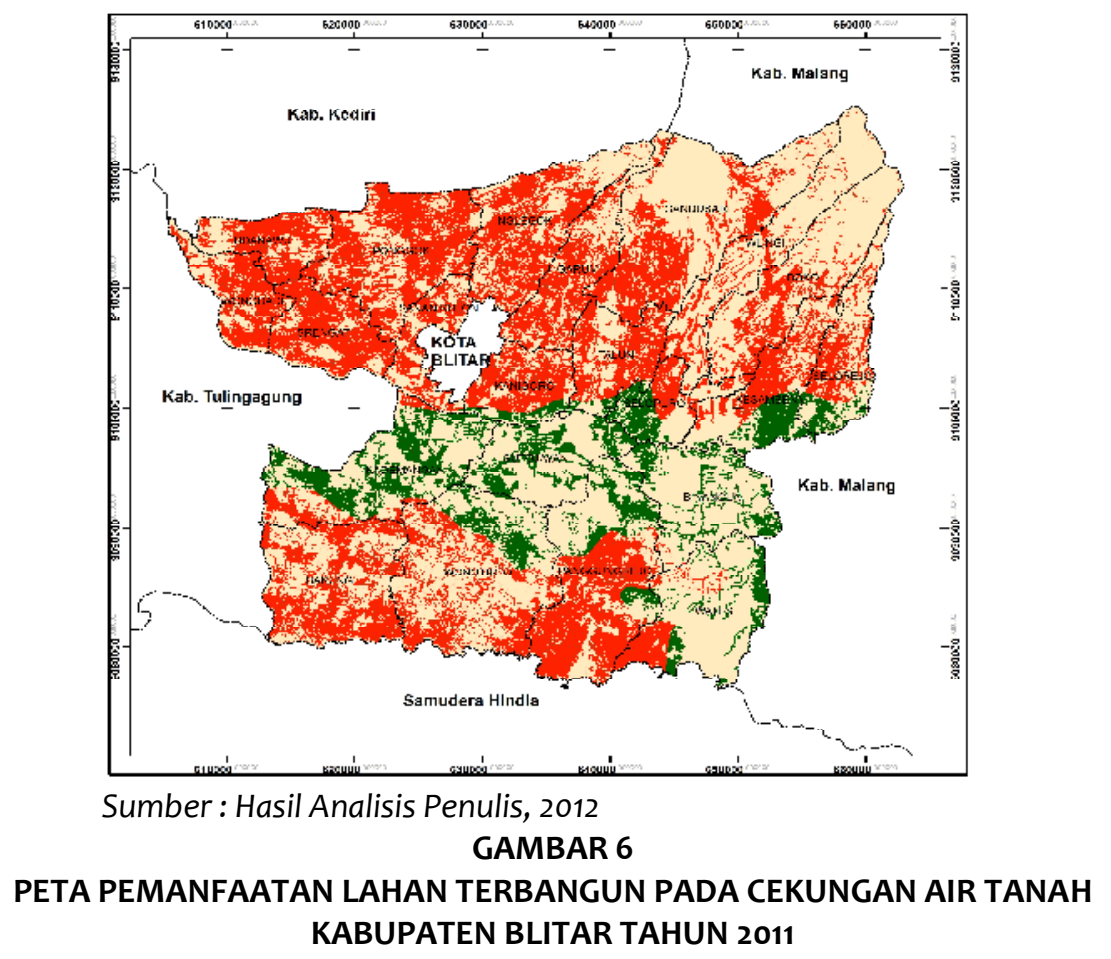

Lahan terbuka merupakan suatu kawasan terbuka tanpa adanya bangunan, termasuk lahan terbuka hijau (Sadyohutomo, 2009). Luas lahan terbuka mengalami penurunan selama kurun waktu 9 (sembilan) tahun sebesar 43.9\%. Berdasarkan Gambar 7, maka luas lahan terbangun di masing-masing CAT, yaitu :

1. Luas lahan terbangun seluas $46,35 \%$ dari luas CAT Bulukawang;

2. Luas lahan terbangun seluas 50,13 dari luas CAT Brantas 


\section{KESIMPULAN}

1. Pemanfaatan lahan di Kabupaten Blitar tahun 2002 dan 2011, yaitu pemanfaatan lahan terluas tahun 2002 berupa sawah seluas 35,63\% dan tahun 2011 telah berubah menjadi lahan permukiman seluas $46,98 \%$. Laju perubahan lahan keseluruhan seluas $44 \%$. Luas pemanfaatan lahan yang berkurang, yaitu sawah, hutan, kebun, perkebunan dan lahan kosong, sedangkan lahan permukiman mengalami penambahan. Kondisi ini mempengaruhi tingkat kemampuan lahan untuk meresapkan air kedalam tanah.

2. Volume infiltrasi di Kabupaten Blitar dalam kondisi surplus. Volume surplus terbesar di Kecamatan Gandusari, sedangkan terkecil di Kecamatan Wonodadi. Volume infiltrasi ini sangat bergantung curah hujan, temperatur, pemanfaatan lahan dan evapotranspirasi.

3. Kebutuhan air total di Kabupaten Blitar Tahun 2010 sebesar 12.485,33 I/detik dengan kebutuhan air terbanyak di Kecamatan Gandusari sebesar 21,81\% dan terkecil di Kecamatan Bakung sebesar $1,26 \%$. Sektor pertanian menjadi sektor terbesar dengan kebutuhan air $84,7 \%$, sedangkan sektor perkotaan menjadi sektor terkecil sebesar $1,87 \%$. Kebutuhan air sektor pertanian ini menjadi sektor yang terbesar di semua kecamatan di Kabupaten Blitar.

4. Ketersediaan air tanah di Kabupaten Blitar berada dalam kondisi surplus. Ketersediaan air tanah terbesar ada di wilayah Kecamatan Gandusari sebesar 12,35\%, surplus terkecil ada di Kecamatan Wonodadi sebesar $0,43 \%$. Kondisi surplus infiltrasi dan ketersediaan air tanah di Kabupaten Blitar tidak merata sepanjang tahun. Pada bulan-bulan kering atau peralihan yang terjadi pada musim kemarau tidak terjadi infiltrasi sehingga ketersediaan air tanahnya minus. Pada daerah Non Cekungan Air Tanah, infiltrasi yang ada hanya mengisi sementara akifer bebas. Pada daerah Cekungan Air Tanah, infiltrasi air hujan dapat mengisi lapisan akifer bebas dan akifer tertekan sehingga dapat dimanfaatkan sepanjang tahun.

\section{DAFTAR PUSTAKA}

Kodoatie, Robert J. dan Roestam Sjarief. 2010. Tata Ruang Air. Yogyakarta: ANDI.

Juanda, Deny dan Lambok Hutasoit. 1999. Panduan Hidrogeologi Umum. Edisi II. Laboratorium Hidrogeologi Jurusan Teknik Geologi ITB.

Kabupaten Blitar Dalam Angka Tahun 2010. Kantor Badan Pusat Statistik Kabupaten Blitar, 2011.

Laporan Akhir Prakarsa Strategis Pengelolaan Sumber Daya Air untuk Mengatasi Banjir dan Kekeringan di Pulau Jawa. 2006. Badan Perencanaan Pembangunan Nasional. www.air.bappenas.go.id. Diakses pada 21 September 2011.

Mock, FJ. 1973. Land Capability Appraisal Indonesia. Water Avaibility Appraisal. Food and Agriculture Organization of The United Nations. Bogor.

Purbawa, I Gede Agus dan I Nyoman Gede Wiryajaya. 2009. Analisis Spasial Normal Ketersediaan Air Tanah Bulanan Di Provinsi Bali. Buletin Meteorologi, Klimatologi dan Geofisika, Vol. 5 No. 2 Juni 2009.

Purwadhi, Sri H. 2001. Interpretasi Citra Digital. Jakarta: PT Grasindo.

Sadyohutomo, Mulyono. 2008. Manajemen Kota dan Wilayah. Jakarta: Bumi Aksara.

Surabaya Post Online. 2011. Pemprov Gerojok Kekeringan Rp. 21 M. Kamis 15 September 2011. www.surabayapost.co.id. Diakses tanggal 22 September 2011.

Suripin. 2001. Pelestarian Sumber Daya Tanah dan Air. Yogyakarta: ANDI. 